\title{
Study of spatial development around the Lutoslawski bridge in Kalinowszczyzna, Lublin
}

\author{
Sofya Matskevich ${ }^{1}$, Slawomir Karaś ${ }^{2}$ \\ ${ }^{1}$ Architecture and Design department (undergraduate), Faculty of Engineering, \\ D. Serikbayev East Kazakhstan State Technical University,e-mail: s_matskevich@mail.ru \\ ${ }^{2}$ Bridge and Road Chair, Faculty of Civil Engineering and Architecture, \\ Lublin University of Technology, e-mail: s.karas@pollub.pl
}

\begin{abstract}
This paper discusses the problem of reviving the Bystrzyca River in Lublin in the vicinity of the historic M. Lutosławski Bridge in the disctrict of Kalinowszczyzna. Historically, this area was an outer part of the city. The north-estern tract turnpike was located there. Until the twentieth century, there was a wooden bridge which was replaced by a reinforced concrete (RC) one. Currently, the space around the bridge is undeveloped. Moreover, there are no parks, recreational areas or cultural venues there. The bridge itself is a technical monument of great value. Despite general awareness of the importance of the bridge, not enough is done to protect it for posterity. The current technical assessment of the bridge indicates its grave condition resulting from rapidly developing corrosion of the carrying $\mathrm{RC}$ elements. The paper describes the surroundings of the bridge and contains some suggestions regarding the use of the bridge as a park avenue and as a stage for music concerts.
\end{abstract}

Keywords: historic RC bridges, Hennebique, technical heritage.

\section{Introduction}

The bridge is located on the street Kalinowszczyzna, which originally was the initial part of the historic route from Lublin to Vilnius. On the basis of a Hennebique company project, engineer Marian Lutosławski constructed an RC bridge as a frame of five spans. It was commissioned in 1908. At that time the reinforced concrete bridge was a major technical achievement due to the progress resulting from the use of RC technology [1].

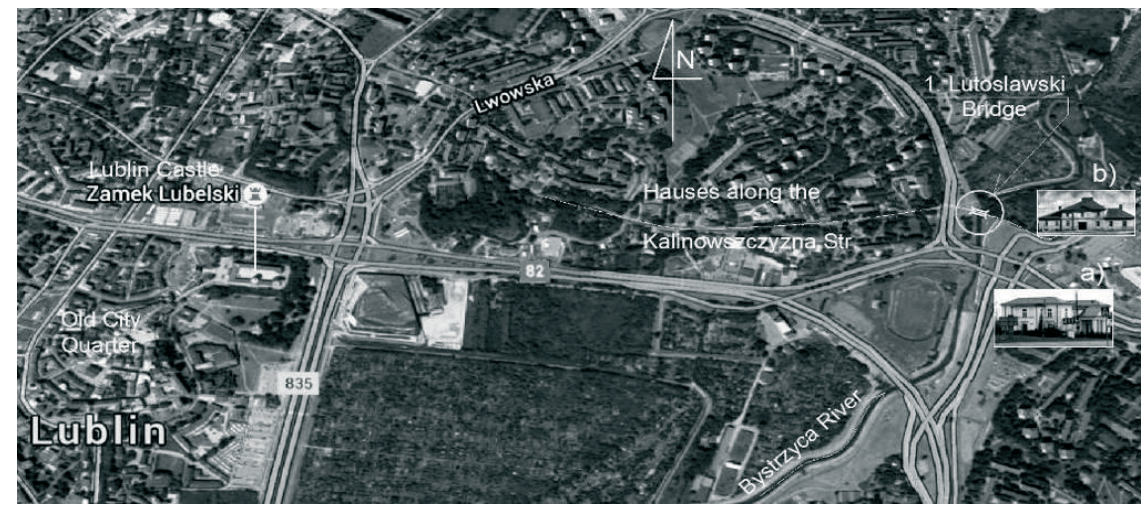

Fig. 1. Localization of the First Lutoslawski Bridge in Kalinowszczyzna, Lublin a) Red Inn b) Graf Manor (by means of Google Maps) 
The green area around the bridge is surrounded on three sides by oppressively busy and noisy streets. For this reason a quiet zone covering the whole area in question should be established. Technically, it is a simple solution that can be achieved by means of transparent or semi-transparent noise barriers of a rather significant height i.e. ca $4 \mathrm{~m}$ to $5 \mathrm{~m}$. This height should provide the acoustic shadow zone covering the whole area. Transparent screens enable eye contact and at the same time the physical separation of the area from noisy surroundings.

In all architectural variations presented below, the way the final appearance of the bridge depends on fulfilling the prerequisite of its renovation. The current technical assessment of the bridge structure, in all technical aspects, is negative.

For various causes, the bridge has never been properly maintained (Fig. 2). This results now in the extensive corrosion of reinforced concrete of virtually all the carrying elements, especially the outer beams in extreme spans. This concentration of the reinforcing steel and concrete corrosion results from the bridge static scheme. The framework has spans of equal lengths. Nowadays, it is commonly known that this results in overloading of the continuous beam sector [3]. Also, the frame pillars show some worrying effects of corrosion, e.g. cracks caused by overload. At the same time the reinforcing steel corrosion can be noticed. As a result of the on-going destructive processes the concrete cover spalling is observed. It regards areas more than one meter long. Despite repeated negative assessments recorded during periodic technical reviews, the bridge administrator has not made any attempt to slow the corrosion processes. Now it is the last moment to take action before the bridge beam collapses. Thus, as has already been said, the renovation of the bridge is a prerequisite for further architectural planning of the bridge surroundings.

a)
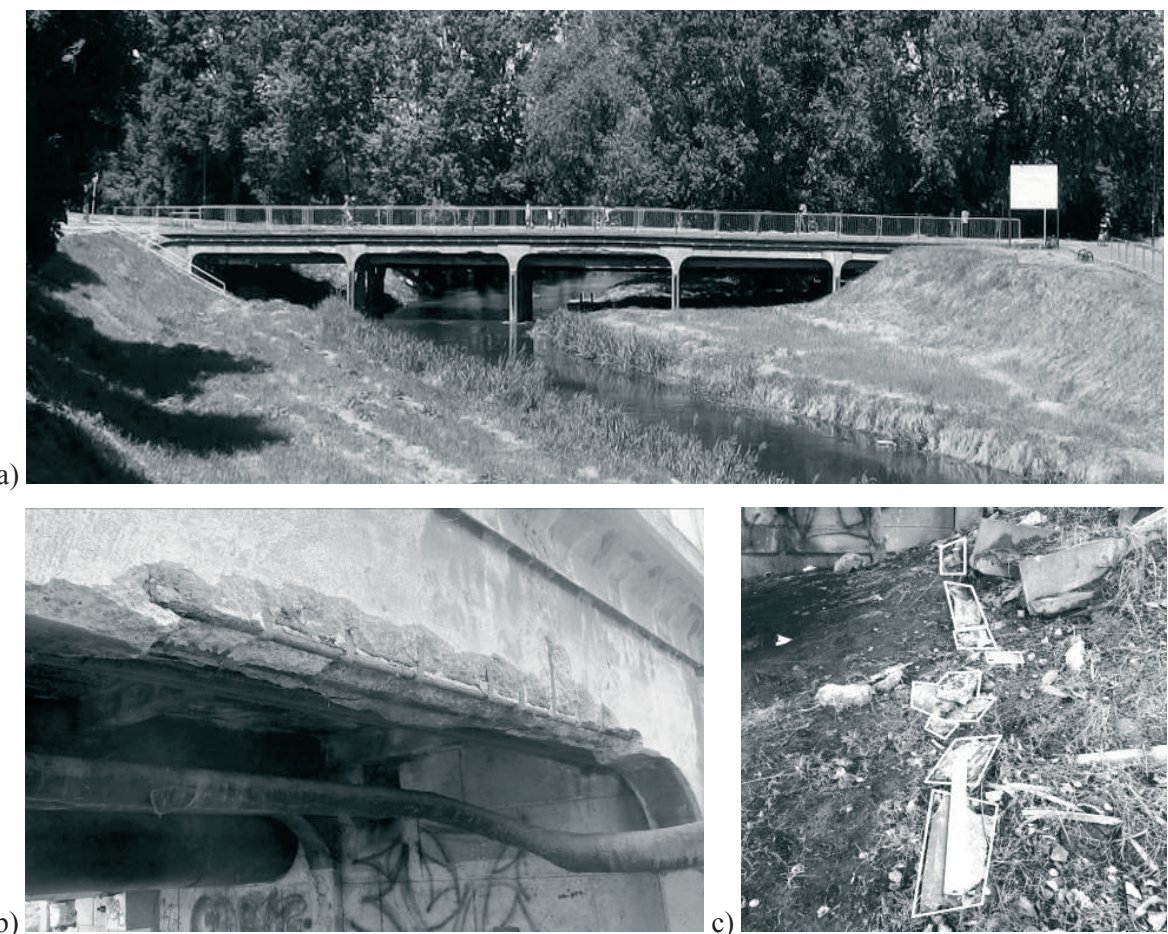

Fig. 2. The 1. Lutosławski Bridge in Kalinowszczyzna, Lublin a) side view b) outer beam corrosion c) fresh peeling of concrete cover of reinforcement (photos b-c were taken on 03.03.2016) 
For the purposes of the reconstruction work, the original technical overall drawing of the bridge, archived in the State Archive of Lublin, is much required (Fig. 3).

Comparing the image of the bridge with the photographs (Fig 1a) and the design drawing, significant omissions and deficiencies become immediately visible.

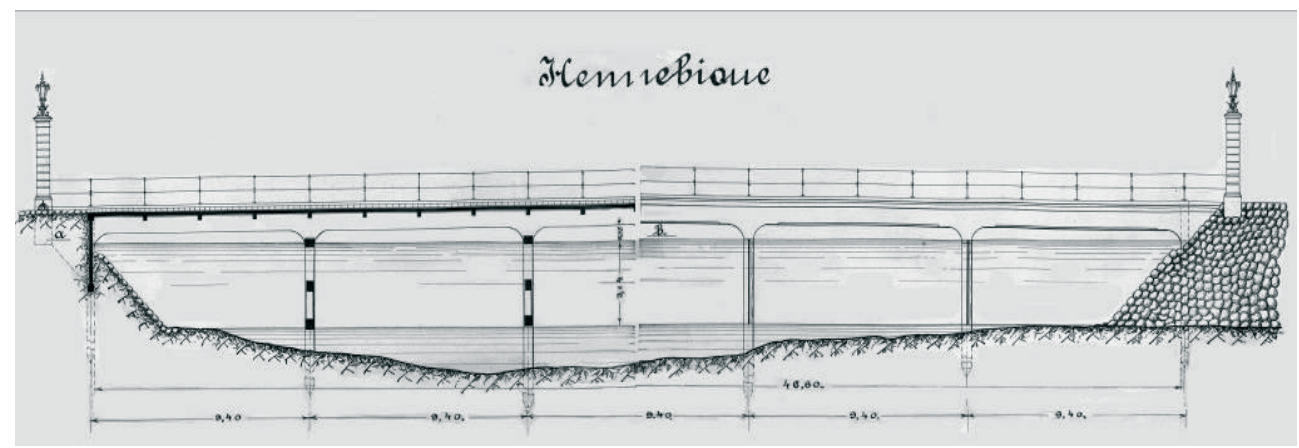

Fig. 3. The longitudinal section (left) and side view (right)

The corner lamps are no longer there. From the original railing only some insignificant parts remain. In fact, even if it survived, it would nor meet the safety requirements of today. Also, the river embankments around the bridge are not strengthened.

\section{Reconstruction proposal}

The reconstruction proposal consists of two parts: simple reconstruction and reconstruction combined with renovation. It is important to make several models to compare their advantages and disadvantages since even at this sketchy stage of works there are various possible solutions.

\subsection{Simple reconstruction}

The main problems to solve on the level of the master plan scheme are: crossing of a busy street with increasing mixed traffic, the moral and physical obsolescence of the bridge, the lack of a parking zone. The general scheme (Fig. 4) contains such zones as a recreational area, transit zone (for bicycles and pedestrians), a small parking lot, a playground for children.

On the basis of a simple reconstruction two options can be proposed: restoration of the original form of the bridge (Fig. 5) or its restoration with added modern elements (Fig. 6-8). In the first case, the reconstruction of the bridge can be based on the surviving drawing (Fig. 3), however, the original metal railing would be replaced by a balustrade for safety reasons. The height of lampposts would be increased in order to create vertical lines in the composition and also a number of lanterns would be added.

In the second case, as additional modern elements tent structures forming the entrances to the bridge would be used. Tent constructions resemble sailing ships or a water splash, which is aesthetically attractive with regard to the location of the object (Fig. 6). Tent structures became especially popular in the 1950-60s thanks to the works of the German architect and engineer Frei Paul Otto (e.g. the West German pavilion at Expo 1967 in Montreal), [4]. 


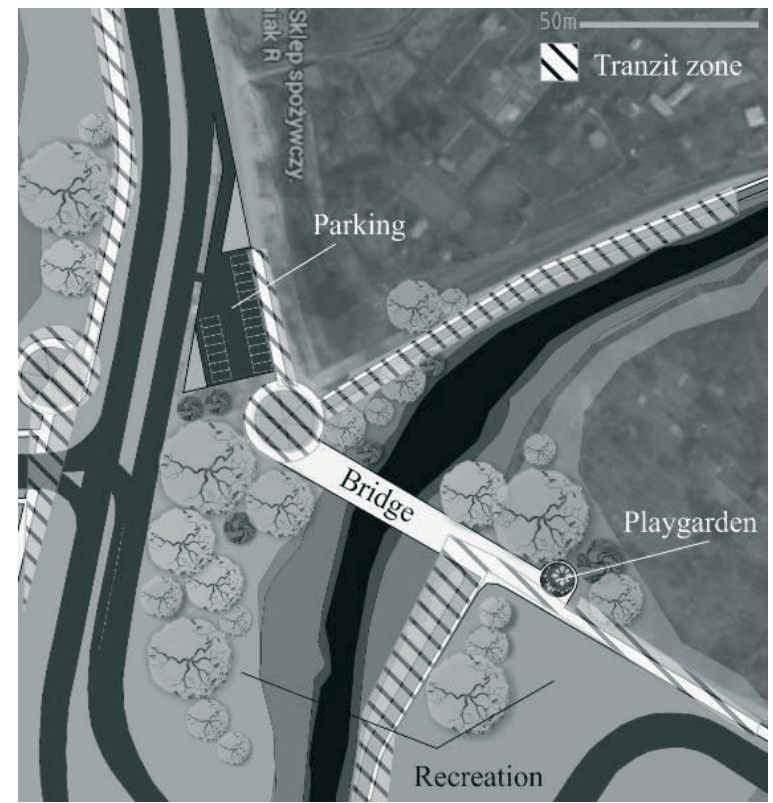

Fig. 4. General plan scheme for simple reconstruction

Different shapes shades set a different mood to the bridge. In the second variant, the tents look like the structural elements of the Magere brug in Amsterdam.

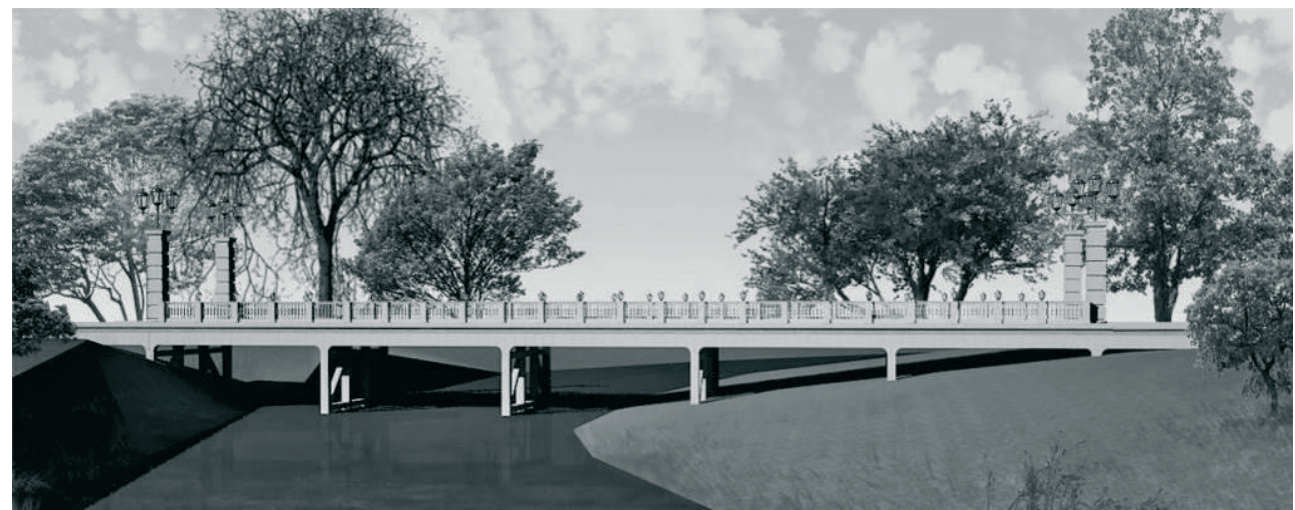

Fig. 5. Simple reconstruction: Restoring the original appearance

Fencing of the bridge is made of glass with sandblasted drawings. The pattern on the glass is a stylistic reference to the period when the bridge was constructed. Glass fencing would make the bridge appear lighter.

Paving in the both cases is provided in two types: basic gray-stone and colored paving connected with the directions of movement. 


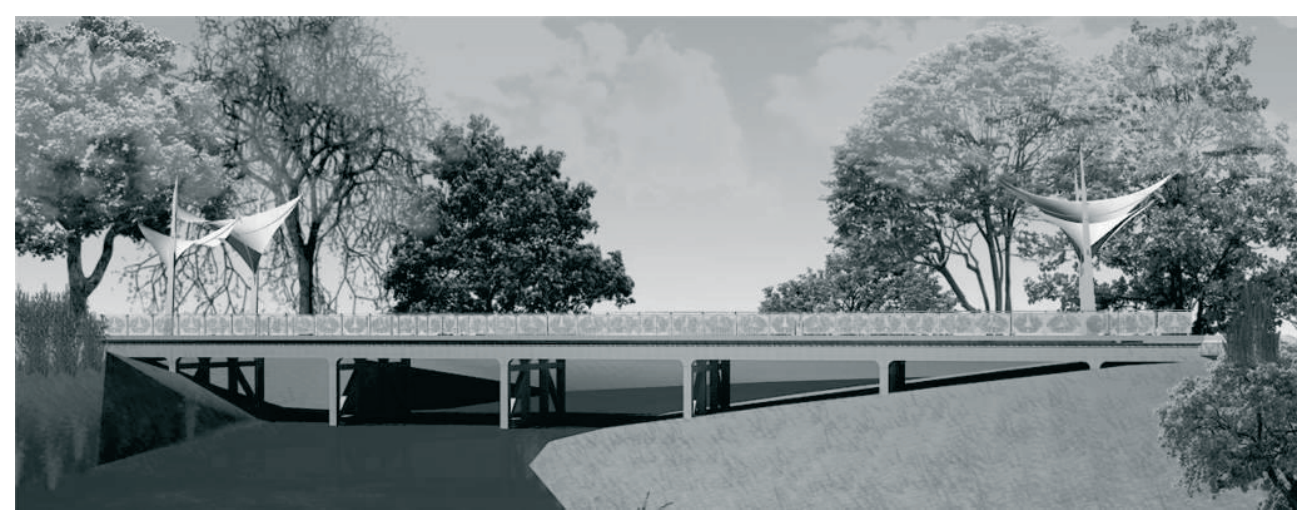

Fig. 6. Simple reconstruction: Adding modern elements: flanking awning as a water splash

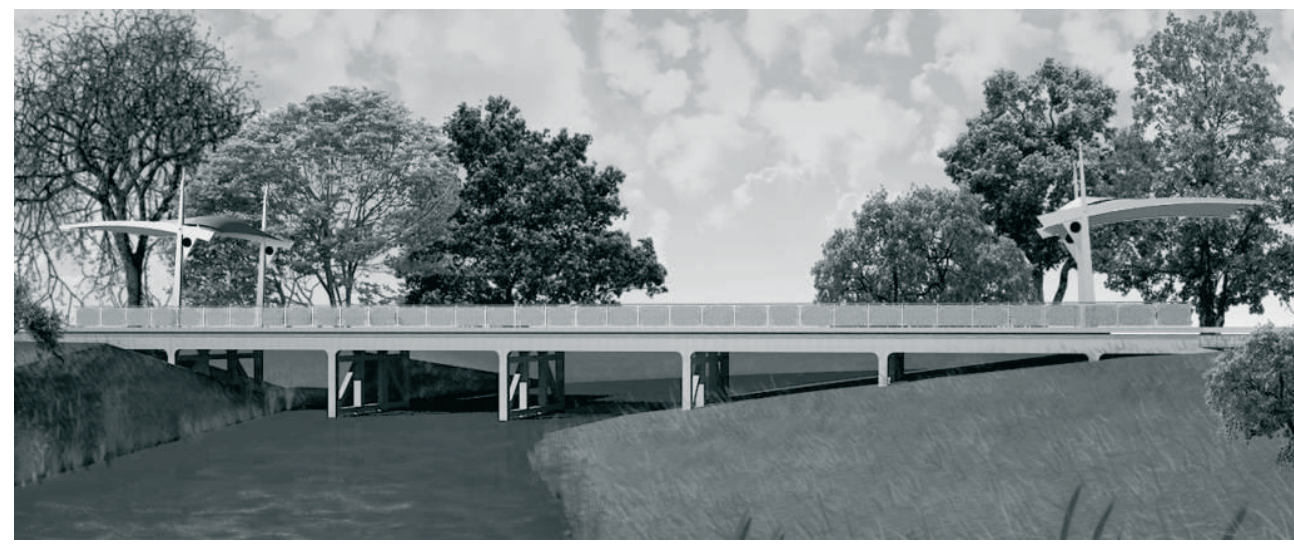

Fig. 7. Simple reconstruction: Adding modern elements: flanking awning as structural elements of Magere brug

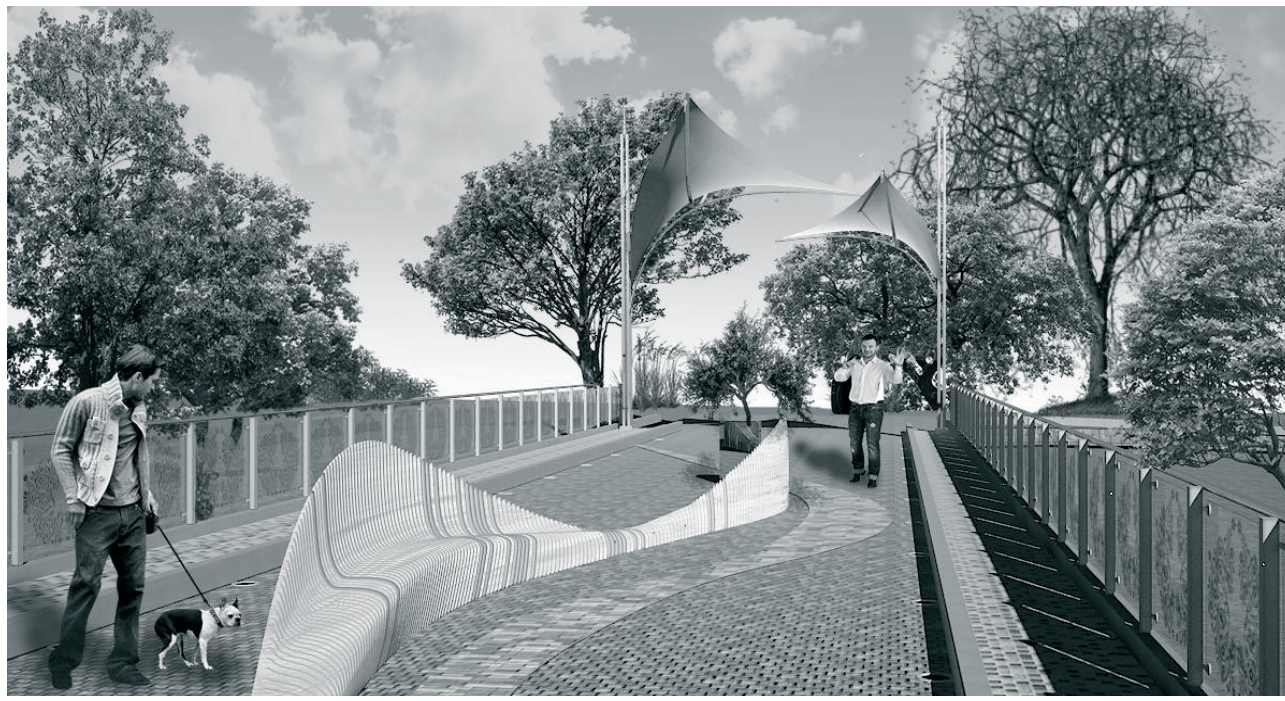

Fig. 8. Simple reconstruction: Adding modern elements: view on the bridge 
The bridge is only used for crossing the river now, therefore to attract people as a free time facility some seating places - which would turn the passage into a park alley should be offered.

In the case of the simple reconstruction, the bridge could also be used an urban space for events. A scene and other necessary objects could be constructed and temporary mobile objects (tents, temporary venues) added, should need arise.

The main advantages of this proposal are: the consideration of the architectural context, a relatively low cost, the appropriate scale of the object.

\subsection{Reconstruction and renovation}

The next part of the proposal is based on the contrast with the existing architectural environment. In the context of sustainable urban development, it becomes necessary to include a number of modern facilities into the landscape of the city, even if the basic method of relevant urban development is conservation. At the same time, sustainable development implies the possibility of concentration of several functions in one place.

This proposal could be classified as event architecture - creation of a space that can be used for various events, including music concerts. This approach greatly enlivens the environment of the city and leads to the intensification of the space use.

The basic motif in the plan design was the water lily: terraces as leaves and a pavilion at the subway as the lily (Fig. 9). The shape of the pavilion echoes the work of Santiago Calatrava (L'Oceanogràfic in Valencia). Compositionally, this element is very important. The proposed radial and symmetrical shape in architectural semiotics denotes the solemnity of space. The pavilion is located on the bridge axis and constitutes a dominant feature on the pedestrians' way.

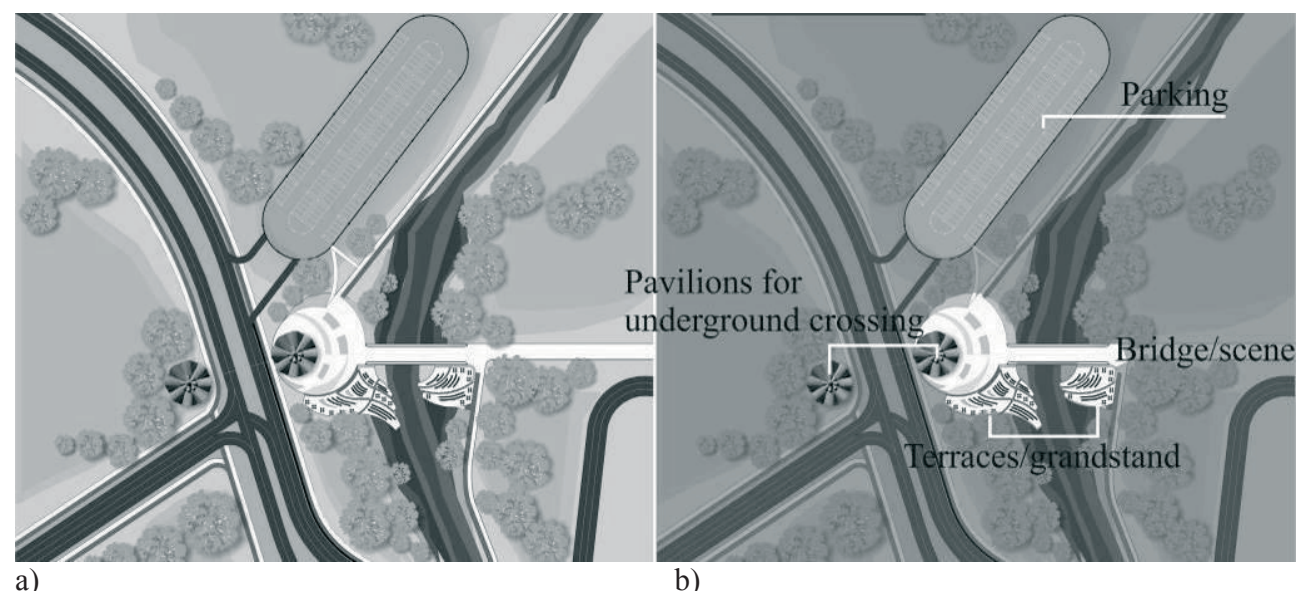

a)

b)

Fig. 9. Reconstruction and renovation: a) general plan scheme, b) explication of general plan scheme

In this variant the additional space is planned in the form of terraced slopes descending toward the river. On everyday basis they can be used as a recreational area, such as a park or playground, and for the period of music concerts or other events accommodate the audience. The bridge is to function as a scene. The audience seating is planned to be located only on one side, because with the scene on the bridge it is important to secure a passage for traffic. 
On the bridge flanking columns with lanterns are foreseen, but their form of will be more modern. Also, the glass fencing mentioned above, bearing a pattern stylistically similar to the patterned fences of the restored bridge on Zamojska Str.

To increase the number of seats it is necessary to enlarge the space in front of the bridge as well as create a parking zone. The future users of the area are passers-by and active observers. That is why a subway under the street has been designed marked by architectural pavilions at the entrance and exit. The pavilions may serve as shops, be used to store concert equipment etc. [5], [6].

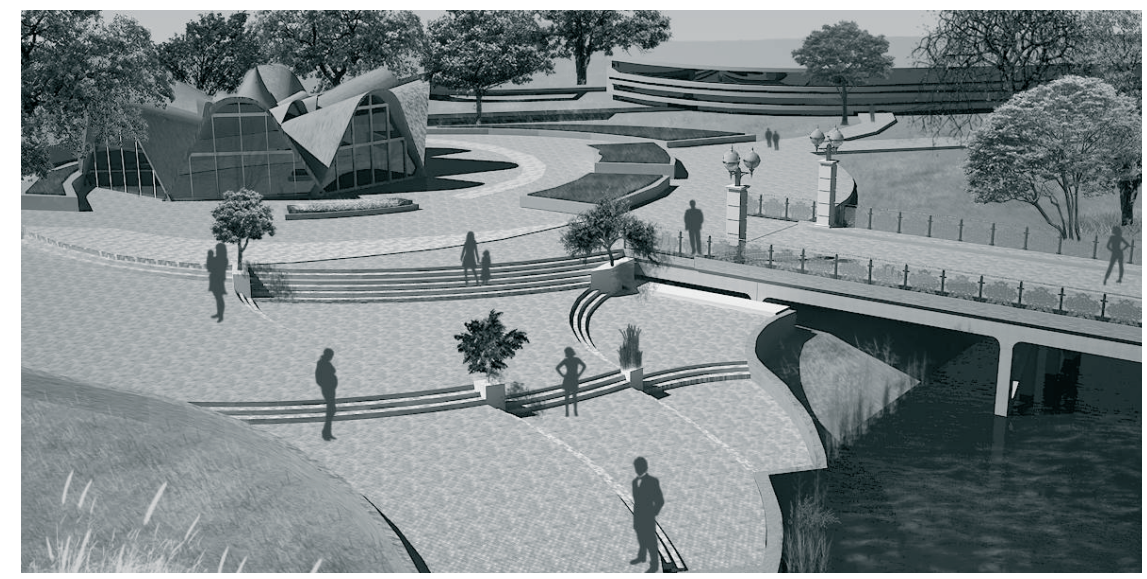

Fig. 10. Reconstruction and renovation: view on terraces and pavilion

The area next to the bridge is foreseen as an ordinary recreational ground easily adapted to the needs of the audience during concerts [7], [8]. The design principle of combining two functions of the bridge, its everyday use and the use during concerts, in the open is similar to analogous cases regarding enclosed spaces [9].

In order to make the space more intimate, on one side of the bridge an entrance arch, decorated with stained glass, could be raised.

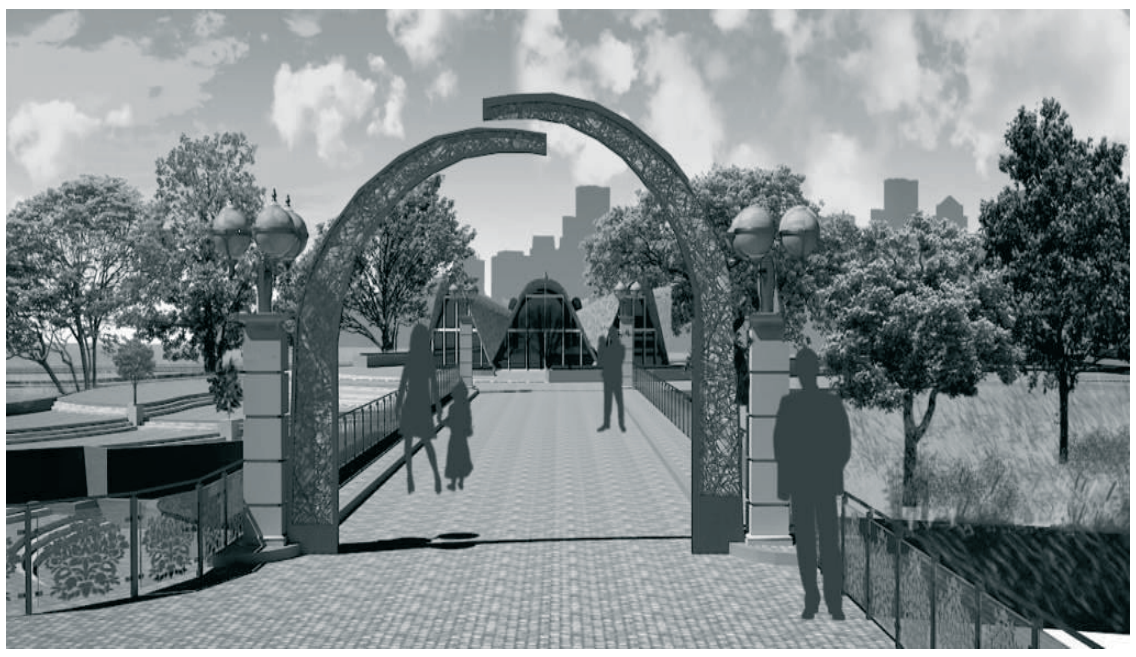

Fig. 11. Reconstruction and renovation: entrance gate with stained glass 
An important question in the case where the bridge is used as a concert venue is sound isolation. Partly, it could be achieved by landscaping, but along the Gen. Wł. Anders Avenue some additional noise screens are needed.

\section{Conclusion}

Event architecture contributes to intensification of urban environment as a result of creating centres of attraction for people. Multipurpose spaces tend to become elements of the urban landscape, maintaining its value for a long time. The inclusion of commercial and other functions can accelerate the return on the investment in the project. The reconstruction of the bridge in Kalinowszczyzna will extend its use for at least 30 years in terms of the bridge structure toughness.

The next step is the development of a greenery zone, including existing and planned trees. This falls into the range of tasks regarding the stylistic concept of the future garden. It would allow to make the bridge more architecturally similar to the surrounding objects (Red Inn, Graf Manor).

Considering very positive experiences with the Bridge of Culture (Lutosławski's Bridge on Zamojska Str.) we can expect analogous results in the case of the bridge on Kalinowszczyzna Str. Therefore here, already from the beginning, a correlation between the renovation of the historical bridge and its new social role, including its green surroundings, has been assumed. That is why the cooperation of architecture and bridge engineering has occurred in the first place.

\section{References}

1. Karaś S. Mosty inżyniera Mariana Lutosławskiego w Lublinie. PWN. Warszawa. 2014. 138 s.

2. Karaś S., Skoczylas.O. Pierwszy most inż. M. Lutosławskiego w Lublinie. Budownictwo i Architektura 13(1) (2014). s. 113-125.

3. Leventis P. The Urban Space of Conflict and Its Reconstruction, University of California, Los Angeles - Architecture., 1996, p. 54 .

4. http://www.freiotto-architekturmuseum.de/index2.html: (03.01.2016)

5. Krier R. Urban spaces - Academy Editions, 1991, p. 175 p.

6. Реконструкция зданий и сооружений. Учебное пособие для студентов строительных специальностей ВУЗов. Под редакцией д.т.н., профессора Шагина А.Л.,Москва, Высшая школа, 1991г. стр. 352.

7. Reconstruction of buildings. Textbook for students of construction specialties. Under the editorship of Prof. Shagina A.L., Moscow, Higher School, 1991, p. 352.

8. Глазычев В.Л., Егоров М.М., Ильина Т.В. Городская среда. Технология развития. - М.: Ладья. 1995. стр. 128.

9. Glazichev VL, Egorov MM, T. Ilyina Urban environment. Technology development. - M .: Rook. 1995. p. 128. 


\title{
Studium zagospodarowania przestrzennego wokól mostu Lutosławskiego na Kalinowszczyźnie w Lublinie
}

\author{
Sofya Matskevich ${ }^{1}$, Slawomir Karaś ${ }^{2}$ \\ ${ }^{1}$ Katedra Architektury i Planowania Przestrzennego, Wydziat Inżynierii Wschodniego Kazachstanu, \\ Państwowy Uniwersytet Techniczny, e-mail: s_matskevich@mail.ru \\ ${ }^{2}$ Bridge and Road Chair, Faculty of Civil Engineering and Architecture, \\ Lublin University of Technology,e-mail: s.karas@pollub.pl
}

Streszczenie: W artykule są rozpatrywane trzy warianty remontu mostu Mariana Lutosławskiego w Lublinie na Kalinowszczyźnie. Jego obecny stan techniczny można uznać za graniczny, ze względu na postępującą korozję żelbetu. Most został wybudowany w 1908 roku. Ze względu na jego historyczną i techniczną wartość, obecnie biegnie proces wpisania tego obiektu na listę chronionych dóbr kultury. Kolejne terminy podjęcia prac renowacyjnych są odsuwane na przyszłość. Jednocześnie zgłaszane są różne propozycje jego przyszłej roli w Lublinie. Odrestaurowany w 2011 roku most Lutosławskiego z 1909 roku został zawłaszczony przez środowiska kulturotwórcze miasta. Most jest nazywany Mostem Kultury. Mając to na względzie, w niniejszym artykule opisana jest analogiczna rola mostu. Tym razem proponuje się by tereny zielone wokół mostu przekształcić w park z główną aleją biegnącą przez most. Poza zwykłą parkową rolą most miałby być również sceną, na której będą organizowane koncerty muzyczne, a zieleń parkowa wokół mostu mogła być łatwo dostosowywana do audytorium. Na rysunkach zaprezentowano kilka możliwych wariantów aranżacji mostu, które obejmują jego projektowaną formę zwykłą i koncertową. W bezpośrednim sąsiedztwie jest usytuowana arteria miejska. Podano przykład separacji ruchu przez wybudowanie podziemnego tunelu. Wejścia/wyjścia z tunelu mają formę niewielkich interesujących form architektonicznych. Zaplanowano również miejsca parkingowe, które mogą być na terenie lub parkingami wielopoziomowymi, podziemnymi.

Słowa kluczowe: zabytkowe mosty żelbetowe, Hennebique, dziedzictwo techniczne. 
